\title{
Resilience as a policy narrative: potentials and limits in the context of urban planning
}

\begin{abstract}
The aim of this paper is to analyse the emergence of the concept of 'urban resilience' in the literature and to assess its potentials and limitations as an element of policy planning. Using a systematic literature review covering the period 2003-2013 and a combination of techniques derived from narrative analysis we show that diverse views of what urban resilience means and how it is best used (as a goal or as a conceptual/analytical framework) compete in the literature. Underlying these views are various (and sometimes diverging) interpretations of what the main issues are and what forms of policies or interventions are needed to address these issues. Urban planners need to be better aware of these different interpretations if they want to be in a position to use resilience appropriately and spell out what resilience can bring to their work. The review also highlights that the notion of urban resilience often lacks adequate acknowledgement of the political economy of urbanisation and consequently does not challenge the status quo which, some argue, is socially unjust and environmentally unsustainable. As such it runs the risk to be seen as simply making marginalised urban communities more resilient to the shocks and inequity created by the current dominant paradigm.
\end{abstract}

\section{Keywords}

Resilience; Urbanization; Climate change; Discourse; Policy narrative 


\section{Introduction}

More than half the world's population now live in urban areas. In low and middle income countries (LMICS), these areas will become home to almost all of the projected $50 \%$ population growth that will occur between now and 2030 , swelling urban populations by a further 1.3 billion by 2030 and 2.5 billion by 2050 (GMR, 2013). As a result, by the middle of the century, urban dwellers will account for more than 85 per cent of the population in the more developed countries and more than 65 per cent in LMICs. Overall, it is expected that 7 out of 10 people will be living in urban areas by 2050 (UN-Habitat, 2011).

In the context of this rapid urban expansion, climate change is likely to become a magnifier of some of the current tensions and pressures around resources (UCCRN, 2011) and the impacts of climate change are expected to pose considerable challenges to cities, especially coastal cities. Changes in sea level, river discharge and weather extremes, combined with increasing potential impacts due to population growth and increasing value of capital, will enhance the need for cities to become 'climate-proof' (Wardekker et al., 2010).

In this context the concept of resilience has emerged as a particularly prominent policy narrative (ICLEI, 2011; World Bank, 2012). It started to receive increasing attention in academic and policy circles in the 1990s, and is now underpinning a growing number of frameworks for integrating climate change adaptation but also other emerging urban issues such as natural disasters, political fragility, or urban inequity, with development planning and programming (Twigg, 2007; DFID, 2011; IRWG, 2012). Resilience is now widely regarded as something that individuals, households, communities or even societies should strive for, in particular in relation to climate change and disasters, and the challenges that those bring in the urban context (Chelleri, 2012; Gasper, Blohm \& Ruth, 2011; Leichenko, 2011; Romero-Lankao \& Dodman, 2011). As such it increasingly diverges from its earlier usage (as a neutral, technical characteristic of a system -see below section), which did not have this normative dimension.

While resilience thinking has a long history in environmental systems (Holling, 1973; Folke, 2006), social dimensions have more recently begun to be integrated, leaving scope to address issues concerning governance, politics and social justice (Leach, 2008; Adger et al., 2009). Yet a growing number of academics still argue that there is a real danger of misuse, or abuse of the term (e.g. Leach, 2008; Cannon \& Müller-Mahn, 2010; Duit et al., 2010; Béné et al., 2012; Bahadur \& Tanner, 2014), as it seems to be increasingly co-opted to accommodate rather than challenge economic or political 
status-quos that are socially and/or environmentally harmful. Some would argue for instance that through their support or reference to the concept of resilience, some institutions are in effect supporting business as usual, possibly with the objective of making communities more resilient to the shocks and inequity created by dominant economic and/or political models. In these conditions resilience fails to support the process of transformation that may be necessary in the long-run, and appears as potentially inadequate as a guiding principle for foresight.

Narrative perspective, which derives from linguistics and constructivism, holds that meaning is a highly contextualised, locally constructed phenomenon that relies heavily on language.... "[N]arrative knowing assumes that individuals perceive the same world differently depending on their values, interests, and histories" (Bridgman \& Barry, 2002, p.142). Following this line of thinking, narrative approaches to policy analysis assume that language does not simply mirror the world, but instead reflects and shapes our view of it in the first place (cf., Fischer \& Forester, 1993; Roe, 1989, 1994). Understanding narrative is therefore critical in relation to science, expertise and the ways this knowledge can be used (or silenced) to justify or legitimize particular decisions and policy orientations.

In the context of urbanization and urban policies, where scientific expertise plays a major role in framing policy debates, it can be argued that any narrative which becomes dominant in policy discussions will be instrumental in shaping the way future urbanization and urban planning will be conceived and implemented. The recent emergence of resilience narratives that are used to analyse and act on urban issues, and provide a goal for individuals, communities, cities or societies, therefore warrants further attention.

With this background, the aims of this paper is to analyse the emergence of the concept of 'urban resilience' in the literature and to assess the potential and limitations of this concept as an element of policy narrative in the context of rapid urbanization. For this, the research relies essentially on a narrative analysis, using secondary data on urban resilience, to identify the different narratives and discourses that exist in the literature around the concept of urban resilience and to analyse how these narratives influence policies around urbanization.

\section{Methods}


A review of the literature was first completed to identify the main existing studies on urban resilience. The result of the review was then used in the narrative analysis. For the review the criteria of inclusion/exclusion were as follow:

- Source: Web of Science + BIOSIS + MEDLINE

- Research Domains: Science Technology + Social Science + Arts Humanities

- Research Areas: Environmental Science Ecology + Urban studies + Sociology + Public Administration

- Key-words in title: 'urban'/'city'/'cities' AND 'resilience'/'resilient'

- Excluded socio-psychological/medical studies of individual (child) resilience in urban context.

- Excluded terrorism/security studies

- Only peer-reviewed material (books and project reports were excluded)

- Published From Jan 2003 to Dec 2013 (10 year period)

- Language: English

The choice of the limited period: 2003-2013 and the category 'title' for the keywords (as opposed to 'title+abstract' or even 'whole document') was deliberate as an attempt to limit the number of articles reviewed to a manageable size. From the initial search, 83 peer-reviewed articles were identified with both key-words 'urban'/'cities' AND 'resilience'/'resilient' in their titles. From these 25 were further discarded as they cover either terrorism/security or socio-psychological/medical issues. The 58 remaining articles were then used in the narrative analysis, with the objective to identify the different narratives present in the literature on urban resilience. As part of this analysis, specific attention was paid to resilience definition(s) (or lack thereof) in relation to these narratives, how resilience was actually used, and the way(s) the underlying problems were defined and framed. We then looked at how these different interpretations of the same initial concept influenced the types of technical solutions and policy orientations that these discourses advocate. The final section concludes by stressing the advantages but also the dangers of adopting such a concept as a new policy narrative without specifically acknowledging the political economy dimension of urbanization.

\section{Narrative analysis}

\subsection{Increasing prominence in the literature}

The notion of resilience is gaining increasing prominence within the literature on cities in relation to shocks and stressors. As Evans puts it (2011, p.22) "The attraction of resilience (...) is fairly obvious". Frequently used terms such as 'climate resilient,' 
'climate- proofing,' and the 'resilient city' emphasize the idea that cities, urban systems, and urban constituencies will need to be able to absorb, adapt or transform in the face of climate related shocks and stressors in the coming future. There is in fact a growing number of studies that propose to explore more rigorously these issues in the literature on urban planning and climate change. Fig.1 illustrates this increasing (in fact exponential) trend based on the 58 articles included in this review, recognizing however the existence of a wider range of publications discussing urban resilience.

[insert Fig.1 here]

\subsection{Resilience as a dynamic, malleable concept ${ }^{i}$}

It also appears rapidly that identifying these different narratives cannot be done by simply providing a 'static' snapshot of the current literature. The different interpretations and definitions of resilience which underpin these various narratives are themselves dynamic and 'malleable'. They have evolved -and are still evolving- over time. The next series of paragraphs below aims at presenting a succinct overview of how the concept of resilience has progressively evolved, branching out from a single ordinary term into a series of different and increasingly sophisticated scientific concepts characterized by different and specific definitions (see Fig.2). For other general or more specific review of the 'genealogy' of the concept of resilience, see, e.g., Leichenko (2011) or Martin-Breen \& Anderies (2012).

[insert Fig.2 here]

In its original day-to-day sense, resilience, which derives from the Latin verb 'resilire' ('to jump back') was used to refer to "the capacity to recover quickly from difficulties; toughness" (Oxford dictionaries). Some authors trace back the first scientific use of the concept to the definition of the 'modulus of resilience' used in the context of 19th century warship design. Naval architect Robert Mallet developed this modulus of resilience as a means of assessing the ability of materials to withstand severe conditions. In the 1940s and 1950s the concept emerged in psychology in the context of the negative effects of adverse life events such as exclusion, poverty, and traumatic stressors on vulnerable individuals and groups -in particular children (Glantz \& Johnson, 1996). The engineering/physic interpretation of resilience (possibly deriving from Mallet's modulus of resilience) became progressively apparent in the 1960s and 1970s, 
where resilience was then formally defined as "the capacity of a material to absorb energy when it is deformed elastically and then, upon unloading to have this energy recovered" (Callister \& Rethwisch 2012, p.216). Soon after, ecologists picked up the concept and started to use it to describe some aspects of ecosystem dynamics around equilibrium. One of the most quoted definitions (often -but wrongly- presented as the original definition of resilience) is that proposed by Hollings in its seminal work on 'Resilience and Stability of Ecological Systems', where resilience was defined as "a measure of the ability of these systems to absorb changes of state variables, driving variables, and parameters, and still persist" (Holling, 1973, p.17).

To some extent Holling's work marks the "renaissance" of the concept of resilience (Bahadur et al., 2010) which started to gain increasing popularity in ecology but also in several other disciplines and sub-disciplines. Disaster Risk Reduction (IFRC, 2004; WCDR, 2005; Klein et al., 1998; Tobin 1999) and then climate change adaptation (Allison \& Hobbes, 2004; Moser et al., 2010; IPCC, 2012) adopted the concept in the 1980s. The IPCC now defines resilience as the 'ability of a system and its component parts to anticipate, absorb, accommodate, or recover from the effects of a hazardous event in a timely and efficient manner' (IPCC, 2012, p.5).

In parallel some social sciences scholars working in close collaboration with the group of ecologists who embraced the concept in the late 1970s, started to apply it to social contexts. Although they did not necessarily seek to define resilience in a specific social sense, they were interested in identifying the characteristics of social systems (groups, communities, society) that would facilitate or foster the resilience of these social systems. Drawing on these two parallel strains, the concept of social-ecological resilience then emerged in the late 1990s (Berkes \& Folke, 1998; Walker et al., 2002), reflecting a new paradigm and meant to overcome the separation of social from natural sciences and to create a new intellectual basis for responding to the 'environmental' challenges of the modern world (Berkes \& Folke, 1998).

Under this social-ecological thinking "resilience (...) is [no longer] simply about resistance to change and conservation of existing structures" (that is the engineering definition) (Folke, 2006, p.7) or even about "buffer capacity and persistence to change while maintaining the same function" (the ecological definition) but instead an emergent property that includes also two other dimensions: the adaptive capacity, that is, "the capacity to learn, combine experience and knowledge, adjust responses to changing external drivers and internal processes, and continue operating" (Berkes et al., 2003); and the transformative capacity, i.e. the "capacity to create a fundamentally new 
system when ecological, economic, or social structures make the existing system untenable" (Walker et al., 2004, p.5).

These various branches constitute the epistemological lineages from which urban resilience emerged in the early 2000s. As we will see later in this analysis, urban resilience did not, however, draw equally from all these different branches. Three schools of thought have been more predominant in influencing the urban resilience narrative: (i) the disaster risk reduction community, initially closely linked to the engineering understanding of resilience, (ii) ecological resilience and (iii) social resilience.

\subsection{From common language to scientific concept and back}

Another key finding that emerges from looking more systematically at the literature is that the precision with which the term/concept of resilience is defined in relation to urban issues varies greatly between articles, irrespective of the actual meaning proposed in the definition. More concretely three levels of 'preciseness' can be identified (Table 1). At the highest level, resilience is defined as a clear (academicallyidentified) concept whereby the author(s) rely either on a new or an existing definition, and often made reference to a specific body of literature. For instance in their analysis of urban resilience in relation to waste management, Agudelo Vera et al. $(2012$, p.3) chose to define resilience "as a measure of robustness and buffering capacity of the system to changing conditions", relying for this on specific reference to Berkes \& Folke, (1998).

[insert Table 1 here]

In other cases the concept of resilience or urban resilience per se is not defined as such, but the authors refer to what a 'resilient city' is expected to look like. Malalgoda et al. (2013, p.73) for instance define a resilient city as "a city that has developed the systems and capacities to be able to absorb future shocks and stresses over time so as to still maintain essentially the same functions, structure, systems, and identity, while at the same time working to mitigate the present causes of future shocks and stresses". In a similar way Leichenko (2011, p.164) defined urban resilience as "the ability of a city or urban system to withstand a wide array of shocks and stresses". In most cases the definition has been derived from ecology theory but explicitly adapted to urban context: 
"By resilience we mean the ability of a city to withstand shocks and threats, to survive stresses and to adapt to social, political, economic and environmental change" (Monteiro et al., 2012, p.113). In some other cases however resilience remains an ecological concept and the 'transferability' to the city is not totally endorsed: Colding (2007) for instance still defined resilience as "the capacity of an ecosystem to absorb disturbance and reorganize while undergoing change so as to retain essentially the same function, structure, identity and feedbacks (Berkes et al., 2003; Carpenter \& Folke, 2006; Holling, 1973)" (p.46 in Colding, 2007). We find a similar approach in Barthel \& Isendahl (2012, p.225) "Social-ecological resilience is defined as the capacity to absorb shocks, utilize them, reorganize, and continue to develop without losing fundamental functions (Carpenter \& Folke, 2006)."

In some other cases the author(s) acknowledge the existence of many different definitions of the term 'resilience' - and even provide these definitions- but do not necessarily select one of them. Instead they embrace this large variety of definition in what Pearson calls a 'pluralisitic use of the term':

"resilience is generally conceived as the ability of a system (e.g. city system) to absorb disturbance and reorganize to retain "essentially the same function, structure, identity and feedbacks" (Walker et al., 2004). We are pluralistic in our use of the term, finding useful insights from; resilience in ecology (Holling, 1973), adaptive capacity in social-ecological systems (Berkes et al., 2003), transition studies in social-technological systems (Rotmans et al., 2001) and adaptation in social systems (Cote \& Nightingale, 2011)." Pearson (2013, p.222 -our emphasis)

Resilience in the urban literature may also be used in a relatively loose manner, i.e. with no specific definition. In some cases a short explanation of that meaning is provided although usually not presented as a proper definition. Boyle for instance (2012, p.352) refers to resilience in the following terms: "this article begins by linking resilience to the broader idea of precaution and argues for an understanding of precaution that includes contingency planning and response alongside the more familiar characteristics of anticipation and preemption". In other cases no explanation is provided but the implicit meaning usually refers to the contemporary sense of resilience "ability to adapt and to bear hardship". Bouzarovski et al. (2011, p.269) for instance present resilience as "part of an expanding scholarly attempt to assess the ability of cities across the world to transform their political, economic and technical structures in line with the demands of a more challenging future environment"). Other examples of loose use of the concept include Gleeson (2008); Antrobus (2011); or Jansson (2013). 
Overall what we observe is a situation where the meaning of resilience in relation to its use in urban context varies along a gradient, from very specifically defined (usually based on a particular definition) to more loosely defined (relying more on the general meaning of the term), to cases where the term may not be defined at all (e.g. Crichton, 2007).

\subsection{Different ways to use the concept of resilience}

In examining the literature on urban resilience, the review highlighted not simply the growing variety of definitions and interpretations of the term 'resilience', but also the large range of uses of the concept. Irrespective of how people interpret or define resilience, the concept is not necessarily always used with the same purpose. Table 2 synthesizes the different utilisations that were identified through the 58 articles included in this review, and provides some examples extracted from the literature.

The first way resilience is used is as a goal, a guiding aim for cities to achieve. The objective in that case is to identify actions, interventions, or policies that ensure that cities are-or become- 'resilient'. For instance in the context of energy, to become 'energy resilient' (that is to operate reliable supplies and stable costs) is regarded as vital for cities due to the growing reliance of developed nations on imported energy and the increased likelihood of supply disruption (Coaffe, 2008). In that case energy resilience is seen as the 'target' and decisions are aimed at achieving this target.

[insert Table 2 here]

A second relatively frequent way the concept of resilience is utilized in the urban literature is as an analytical framework to help us think about certain issues and find adapted solutions. A good illustration of this approach is Liao (2012) who proposes two interpretations of resilience (engineering and ecological resilience) to develop a theory on "urban resilience to floods" as an alternative framework for urban flood hazard management. Other examples include Wardekker et al. (2010) or Ernston and his colleagues (2010) who propose to use resilience theory to help rethinking urban planning in particular in the face of uncertainty:

"the traditional paradigm of planning for a predictable future is not only insufficient, but it may, in some ways, also be destructive. This article strives to lay a foundation for transitions in urban planning and governance, which enable cities to navigate change, build capacity to withstand shocks, and locate sources of experimentation and innovation 
in face of uncertainty. (...) resilience theory from ecological research can contribute to our thinking on this normative goal." (Ernston et al., 2010, pp.531-532).

These first two ways to use resilience (as a goal and as an analytical framework) will be discussed in greater detail in the next section. The third way resilience is used in the urban literature is as a metaphor, that is, as a tool to favour and foster integrated approach in relation to urban planning. "Metaphor is a powerful tool for creating new ideas and syntheses, which can suggest how to use an idea or approach developed in one realm in an entirely different realm. [In the present case, the concept of] resilience used as a metaphor can help link ecology and planning." (Pickett et al., 2004, p.369). Interestingly this role as "mobilizing metaphor" to integrate and mainstream sectors that are traditionally disconnected is also highlighted in other domains such as development (Béné et al., 2014) or food security (von Grebmer et al., 2013; Béné et al., 2016), where resilience is used to bring together traditionally disparate communities such as disaster risk reduction, climate change adaptation, and social protection.

One more recent use of the term resilience in the context of urban planning is as an 'indicator'. Evans (2011) for instance proposes to use resilience as an indicator of sustainability: "Based on non-equilibrium theory, complexity and non-linearity, the most recent ecological incarnation of the city is distinctive in emphasising resilience and adaptive learning as the path to urban sustainability in the face of climate change" (Evans, 2011, p.224). Based on this, Milman \& Short (2008) developed a "Water Provision Resilience (WPR), which serves as an example of how resilience can be incorporated into indicators of sustainability". The second case where resilience is used as an indicator of sustainability is in Monteiro et al. (2013) where these authors propose to use Chronic Obstructive Pulmonary Disease (COPD) as a "good motivator to encourage greater acceptance of interventions that aim to improve the urban resilience to diverse risks". In that case resilience is also seen as the goal -but understood as a way to ensure urban sustainability: "COPD as a resilience promoter tool in urban sustainable planning" (Monteiro et al., 2013, p.113).

Finally due to the attention that it has been receiving from donors and media (see e.g. The Economist, 2014), the concept of resilience has also been recently under the growing risk of becoming nothing more than a buzzword. As such, the last two categories listed in Table 2 ('resilience used as a buzzword', and 'no use beyond the title') may sound initially of little interest. Some would argue however (correctly) that these types of (mis)use should -or could- deserve more attention, not the least because 
they are contributing to the "lax applications and sloppy implementation [that] are hindering its usefulness" (Pearson, 2013, p.222).

\section{Mapping the different resilience narratives}

Building on the results presented above we now propose a 'map' of the concept of resilience as currently used in the urban literature. Our main objective will be to identify the main narratives that are found in this part of the literature, and to 'unpack' the way they are constructed and legitimized. Eventually the analysis will reveal how these different interpretations of the same initial concept influence the types of technical solutions and policy orientations that these discourses advocate.

\subsection{Resilience as a goal for urban planning}

The vast majority of urban resilience papers identified in the literature refer to resilience as an objective which cities should try to achieve through appropriate planning, policies and interventions. For most of these studies, resilience is therefore perceived as a positive characteristic that needs to be strengthened.

This normative interpretation leads experts to present resilience as the ultimate goal to be sought in many different contexts and in response to many different issues. In the examples presented in Table 3 these issues include climate change issues, food insecurity, or the 'unsustainability' of the current urbanization. For Evans (2011, p.225) for instance:

"If climate change is the driver and resilience the goal, then adaptation is the process through which transition will occur (...) Within this context, [planning] experimentation is supposed to prompt radical social and technical transition by testing out different technologies under a range of conditions in highly visible ways".

[insert Table 3 here]

For Agudelo Vera and her colleagues, the problem is not "the inevitability of climate change" (Evans, 2011, p.223) but the "un-sustainability of the cities". "Considering the current level and rate of urbanization and growing ecological footprints, the impact of inadequate urban resource management has become a global issue. (...) The root of the 
current urban un-sustainability is the massive resource consumption and waste production beyond natural supply and recycling limits" (Agudelo Vera et al., 2012, p.3) and the process through which the resilience of the cities can be restored is technical change. In that context the technical 'solution' is the concept of urban harvest presented "as a management tool towards more resilient cities" ( $p .4)$ : "By harvesting urban resources, global impacts are reduced and the resilience of cities can be improved as well (p.3).

Other examples in Table 3 include food insecurity (de Zeeuw et al., 2011), or (again) unsustainable urbanization (Colding \& Barthel, 2013), or climate change (Rijke et al. 2013). In all these cases, resilience is the goal that is reached through various impact pathways: through increase in food availability made possible through peri-urban agriculture for de Zeeuw et al. (2011); through biodiversity conservation and urban green commons (UGCs) for Colding \& Barthel (2013); or through social change and transformative governance for Rijke et al. (2013).

In all these examples resilience is eventually what we need to achieve. Taken individually these different uses of the concept of resilience are well constructed and robust. However, once put together into one single framework, resilience appears as the ultimate goal for many different pathways. In fact, the comparison of Agudelo Vera et al. (2012) and Colding \& Barthel (2013) reveals how the same initial issue (unsustainable urbanization) calls for different processes ('Technical changes' according to Agudelo Vera et al. and 'Biodiversity conservation' for Colding \& Barthel) and different practices ('Urban harvest' for Agudelo Vera et al. and 'UGCs' for Colding \& Barthel), yet leading to the same result ('Urban resilience'). Note also that in all those different positive portrayals of resilience, underlying structural inequalities or power asymmetries are not questioned.

\subsection{Resilience as an analytical framework in the context of urbanization}

Resilience has been adopted by many researchers as the basis for analytical frameworks that help understand how systems respond to shocks and stress. Examples from the literature on social-ecological systems include Carpenter et al. (2001); Berkes et al. (2003); Walker et al. (2006); Chaplin et al. (2009). A current discussion is also taking place in the development literature, in two different directions: one in relation to disaster risk reduction (see e.g. Levine et al., 2012), and one in relation to food security (see, e.g., von Grebmer et al., 2013; Béné et al., 2016). 
[insert Table 4 here]

The growing numbers of articles which explore the way resilience can be used as an analytical framework in the context of urban studies is not necessarily surprising and we already presented some examples in the previous section. As Evans explains (2011, p.233): "the writings of resilience ecology replacing the language of generally applicable knowledge [helps] discovering generally valid meta-principles and frameworks". Table 4 captures some of these examples. While the table does not claim to be comprehensive, it illustrates the process and also highlights the salient points of this part of our analysis.

Barthel \& Isendahl (2013) is our first example. In their paper those authors choose social-ecological resilience as "the analytical lens" (p.225) for their analysis of urban food security system. They identify two 'meta-principles' that are closely associated with social-ecological resilience, namely (i) diversity and redundancy and (ii) memories, experiences and learning, and "apply these principles of resilience in an inclusive manner, beyond the strict behavior of sets of species in an ecosystem" (p.225). Relying on two case-studies from widely different historical and cultural contexts - the Classic Maya civilization of the late first millennium AD and Byzantine Constantinople - they then use these two meta-principle to 'demonstrate' that urban farming has been (at least in the past) a pertinent feature of urban support systems, and that, in that context, urban gardens, agriculture, and water management as well as the linked socialecological memories of how to uphold such practices over time have contributed to long-term food security during past eras of scarcity.

Ahern (2011) in the second example in Table 4uses resilience theory to help identify which characteristics urban planning should embrace in order to be able to address the contemporary challenges that urban zones and cities are facing, and in particular to be adaptable. Relying on lessons from social-ecological resilience literature he identifies a suite of five principles (he called these 'strategies') that are necessary to build urban resilience capacity, namely: multi-functionality, redundancy and modularization, (bio and social) diversity, multi-scale networks and connectivity" (Ahern, 2011, p.341).

To a large extent the title of Baud \& Hordijk 2009's paper -the third example in Table 4 "Dealing with risk in urban governance: what can we learn from 'resilience thinking"' says it all. Claiming that "Uncertainty, unpredictability and change have become key characteristics of today's interdependent world" (2009, p.1069) -a claim that perhaps underplays the levels of uncertainty, unpredictability and changes that were already at 
work in the past- the two authors propose to identify the main characteristics of resilience thinking and adaptive governance that appear relevant for urban planning. They conclude that these characteristics include flexible institutions, knowledge systems that integrate different sets of knowledge, and the capacities of learning by experiment, creativity and self-organization.

None of the three papers presented here provide however clear detail of the procedure, criteria, or rational they relied on to identify the meta-principles or characteristics of resilience which they claim are key to address the issues they were focusing. Yet, they are quite illustrative of a larger pool of papers which, in the same way, draw on the resilience thinking as a source of 'analytical solutions' for different urban issues.

\subsection{Unfolding the main narratives on urban resilience}

As illustrated above, resilience can be understood and interpreted quite differently in relation to urban literature. That heterogeneity in the usage and interpretation is partly rooted in the different intellectual origins and lineages as presented in section above (cf. Fig.2), and there can be large disagreement on both the main issues that need to be addressed and the main characteristics that define urban resilience. In fact even within those schools of thought, a certain level of diversity of interpretation can be observed.

Three generic schools can be distinguished: (1) urban hazards and disaster risk reduction; (2) urban ecological resilience; and (3) urban resilience through governance and institutions. In addition to these, at least two other major schools of thought which are not directly related to urban literature but strongly influence part of the discussion should be mentioned: (1) socio-technological transition; and (2) social-ecological resilience. Those various groups are synthesized in Table 5 and represented on Fig.3. Note that the aim of Fig. 3 is to capture and contrast the distinctiveness of the each of the main schools of thoughts. As such it is represented as a 'static' snapshot that does not reflect the more fluid and dynamic evolution which led to these different schools of thought -something that was partially captured in Fig.1. The next subsections present in greater details these different schools of thought, their main features and how they are linked to different degrees to each other.

[insert Fig.3 here]

[insert Table 5 here] 


\subsubsection{Urban hazards and disaster risk reduction}

The first (and possibly largest) school of thought that anchors its work on resiliencethinking in the urban context is that of "urban hazard and disaster risk reduction" (Table $5)$. This includes the work of researchers and practitioners working on issues revolving around natural and human-made hazards in the urban context. A large part of this work is closely related to, and claimed its origin in, the increase in frequency and intensity of climate change related disasters and extreme events. Emblematic of this work are the numerous articles that have been published following the hurricane Katrina in New Orleans (see e.g. Campanella, 2006). Other main streams of work in this thread are the articles discussing flood events (e.g. Khailani \& Perera, 2013; Liao, 2012) such as the 2010 Pakistan flood or the 2011 Bangkok, or more general considerations about urban planning in relation to disasters (e.g. Malalgoda et al., 2013), as well as the social components (e.g. social network, participatory planning) that are important in building urban resilience to disaster (Wardekker et al., 2010; Smith et al., 2011). Although not exclusively on Asia - presented as the "epicenter of the current urbanization surge" (Shaw et al., 2009, p.101) - a large part of the work in this thread does focus on this region of the world where the occurrence of climate-related extreme events is noticeable.

Logically the underlying narrative of this thread is the increasing threats induced by climate-related events, and the likely vulnerability of these within cities and urban centres who are at the bottom of the social ladder: "It is predicted that the severity and frequency of climate change induced disasters will increase and those who have the least to cope with would be the most vulnerable" (Shaw et al., 2009, p.104). In that context, cities in LMICs are recognized to be at particular risk from climate hazards (Lavell et al., 2003; Bull-Kamanga et al., 2003).

Not surprisingly, the concept of resilience in this thread (although it remains somewhat contested -see below) is broadly interpreted as referring to the ability of the system to persist and to adapt in the face of climate shocks and stresses. There is, in particular, a tendency to emphasize the importance of infrastructure and physical elements, and the ability to resist shocks. As explained by Malalgoda et al. $(2013$, p.75) attention is drawn to "physical systems [such] as built roads, buildings, infrastructure, communications, and energy facilities as well as waterways, soils, topography, geology, and other natural systems. The physical systems act as the body of the city, and at a time of a disaster, the physical systems should be able to withstand its effects under extreme stresses". 
In that context a critical part of resilience is related to the robustness of the system and as expected several definitions of resilience reflect this emphasis: "Resilience is a measure of robustness and buffering capacity of the system to changing conditions" (Agudelo Vera et al., 2012, p.3).

In flood hazard management, (...) resilience is the rate of return from a flood-impacted state to the normal one (De Bruijn, 2004).... Recovery is often interpreted as returning to predisaster conditions, implicitly assuming an optimal reference state" (Liao, 2012, p.3)

Under this interpretation a resilient city is "a city that has developed the systems and capacities to be able to absorb future shocks and stresses over time so as to still maintain essentially the same functions, structure, systems, and identity, while at the same time working to mitigate the present causes of future shocks and stresses" (Resilientcity.org, 2010). Indeed the idea is that "[m]any disasters could be avoided by way of good housing, infrastructure and services; being equipped with the necessary resources and being capable of organising itself before, during and after a hazard" (Malalgoda et al., 2013, p.75-76).

From this urban hazard and disaster risk reduction approach, the key characteristics of resilience focus on the recovery process, where the preoccupation is the stability/equilibrium of the system: "In many cases, resilience is taken to mean exclusively the capacity to bounce back to the predisaster state" (Liao, 2012, p.3). This engineering vision of what resilience is about can be summed up by the following series of key-words: Infrastructure / buffering / resistance / protection / recovery / equilibrium (Table 5, see also Fig.3 bottom left part of the diagram).

This interpretation of urban resilience is however increasingly challenged (from inside and outside) by authors who claim that resilience involves much more than simply rebuilding and that physical infrastructures are not everything. Campanella for instance reflecting on the experience of New Orleans argues that:

"cities are more than the sum of their buildings. They are also thick concatenations of social and cultural matter, and it is often this that endows a place with its defining essence and identity. (...) To enable total recovery, familial, social, and religious networks of survivors and evacuees must be reconnected" (Campanella, 2006, p.142).

Another line of internal criticisms emerges from scholars (e.g. Liao, 2012) who (drawing on the ecological interpretation of resilience and in particular Holling's work), argue that 
even from a physical/infrastructure perspective resilience is not about equilibrium and stability, but about non-equilibrium and flexibility. In the case of flood for instance resilience should not be interpreted as the ability to avoid flood, but instead as the ability to live with flood. Some argue that this ecological interpretation of resilience is more useful for urban planning and design because it is more dynamic and evolutionary. Under this non-equilibrium paradigm, resilience is the ability of a system to adapt and adjust to changing internal or external processes.

\subsubsection{Urban ecological resilience}

Moving away from the static/equilibrium angle and up along the left hand side of the resilience triangle on Fig.3, we find a second major school of thought on urban resilience, one that promotes the urban ecological dimension of resilience.

The urban ecological resilience literature, which draws on and extends traditional notions of ecosystems resilience, has an almost antagonist interpretation to the urban hazard and disaster risk reduction vision, regarding (a) what the issues are, and therefore (b) what the solutions should be. For the academics belonging to this urban ecological resilience school, the main source of concern is the impact that the rate of urbanization has on ecosystems, biodiversity, and natural cycles. For them, the current pace of global change is unprecedented. Considering the current level and rate of urbanization and growing ecological footprints, some of the central issues are the rapidly declining availability of resources such as oil, freshwater, phosphorus, metals; and the disruption of natural cycles, for instance nitrogen and carbon-cycle (Boyle et al., 2010; Gordon et al., 2006; Rockström et al., 2009).

In essence, the narrative underlying this approach is that cities are unsustainable and are threatening our ecological environment (Table 5). As explained by Agudelo Vera and her colleagues:

The root of the current urban un-sustainability is the massive resource consumption and waste production beyond natural supply and recycling limits (...). Therefore, cities worldwide are facing the challenge to find and implement alternative strategies (Cola et al., 2005) towards more sustainable management of urban resources (Agudelo Vera et al., 2012, p. 3).

Several ecological footprint studies estimate for instance that cities greatly exceed, or overshoot, their bio-capacities by typically 15-150 times (Doughty \& Hammond, 2004). Cities are not sustainable because they do not use resources efficiently. In general, cities 
have a linear usage of resources and waste production, without feedbacks of resources in terms of quantity and quality (Leduc et al., 2009).

Others are not as much concerned by the level of waste as they are by the impact of cities on biodiversity and ecosystem, and the degraded capacity of these ecosystems to deliver their different services. "While cultural diversity is increasing in cities at a global level as a result of urbanization, biodiversity is decreasing with a subsequent loss of ecosystem services" (Colding \& Barthel, 2013, p.156). In these conditions the benefits that urban inhabitants and cities derive from ecosystem processes including, e.g., improved water and air quality, storm protection, flood mitigation, sewage treatment, micro climate regulation, and recreation and health values, are being jeopardized or even irreversibly damaged (Ernston et al., 2010).

Resilience here is therefore closely related to ecological processes and dynamics, and is defined in line with this ecological focus: Resilience "is used here as the capacity of an ecosystem to absorb disturbance and reorganize while undergoing change so as to retain essentially the same function, structure, identity and feedbacks (Colding, 2007, p.46) -see also Jansson \& Polasky (2010); or Jansson (2013); or Colding \& Barthel (2013) for similar definitions. In fact some scholars even go as far as stating that resilience was at its origin an ecological concept, and that is part of the reason why urban resilience has so far been neglected: "given its origins in ecology, it is not surprising that most resilience scholars have historically been interested in empirical analyses of non-urban areas (e.g., shallow lakes, production forests, and small-scale agriculture (...), and have devoted less attention to the specifically human and social elements of humandominated systems, such as cities" (Ernston et al. 2010, p.533-our emphasis). Some authors go as far as talking about "ecological resilience of urban ecosystems" (Alberti \& Marzluff, 2004, p.241).

This vision of resilience as being fundamentally an ecological concept is relatively narrow and seems to ignore a large part of the literature on resilience, but it illustrates relatively closely some elements of the narrative adopted by this school of thought: "cities are unsustainable and have been lacking ecological resilience, we need therefore to 'inject' more resilience into these cities to make them more resilient". How do we do that? First by promoting the conservation or the restoration of urban biodiversity: "There is increasing scientific evidence on the essential role of biodiversity for building resilience in a changing world" (Jansson, 2013, p.286). "Biodiversity along with social, physical, and economic diversity, are important and effective strategies to support urban resilience“ (Ahern, 2011, p.342). The argument here is that biodiversity can play 
the role of 'insurance' again risk and shock: "with a greater number of species performing a similar function, the ecosystem services provided by any functional group - for example, the decomposers - are more likely to be sustained over a wider range of conditions, and the system will have a greater capacity to recover from disturbance" (Ahern, 2011, p.342). In this part of the narrative, management of diversity is considered to be a key attribute for building resilience. Diversity spreads risks, creates buffers (Berkes et al., 2003). As such diversity is seen as key for dealing with disturbance and change in productive ways, with self-organization and the capacity for learning and adaptation constituting important resilience characteristics. In sum the keycharacteristics that are emphasized in this ecological urban resilience are: (bio)diversity; diversification; (urban) ecosystem-services.

As with the disaster risk reduction literature, the interpretation of ecological urban resilience has also evolved over time. From a strong and narrow focus on urban-based ecosystems (e.g. Alberti \& Marzluff, 2004; Jansson \& Polasky, 2010), it has progressively moved to a more integrated analysis of urban coupled human-environment systems (Pickett et al. 2004), and examination of cities and urban networks as complex adaptive systems (Resilience Alliance, 2007). Within this literature, the promotion of Urban Green Commons (UGCS) is illustrative of this recent effort to integrate better social and ecological dynamics. Some would have seen in these UGCs the continuation of the predominance of ecology on this urban resilience narrative. Yet, the emergence of UGCS in the literature was based on their ability, as common property systems, to stimulate and promote some degree of environmental stewardship and social-ecological memory, which in itself was seen as promoting urban resilience (Colding \& Barthel, 2013).

Similarly Urban and Peri-urban Agriculture (UPA) which also emerges in this literature is praised not only for its ecological properties (such as maintaining green open spaces and enhancing vegetation cover in the city, or reducing energy use and greenhouse gas emissions by producing fresh food close to the city) but also for its social 'properties' including poverty alleviation and social inclusion; urban food and nutrition security; and reducing vulnerability of specific groups (de Zeeuw et al., 2011)

\subsubsection{Urban resilience through governance and institutions}

The third main thread in this urban resilience literature is the 'Urban resilience through governance and institution' (Table 5). In this thread, the analysis is focused on questions of how different types of institutional arrangements (e.g. participatory planning) and governance systems (e.g. decentralized governance) affect the resilience of cities (e.g. Tyler \& Moench, 2012), and how, in turn, resilience thinking can influence the 
development of improved governance mechanisms for promoting effective disaster risk management and adaptation to climate change (see e.g. Wallace et al., 2007; Evans, 2011; Pelling \& Manuel-Navarrete, 2011). This includes in particular studies on how resilience principles such as adaptive management can be used in exposed coastal areas (Wardekker et al., 2010) and which characteristics of urban governance can enhance climate resilience while at same time reducing vulnerability of urban citizens who are most at risk to climate-related shocks and stress (Tanner et al., 2009).

The narrative, here, is one where cities are described as facing uncertainty and increasing unsustainable conditions and challenges and will need to 'navigate' the necessary changes and transitions:

“... we are facing an increasing uncertainty due to climate change, migration of people, and changes in the capacity of ecosystems to generate goods and services. In an urban context, this means that the traditional paradigm of planning for a predictable future is not only insufficient, but it may, in some ways, also be destructive. This article strives to lay a foundation for transitions in urban planning and governance, which enable cities to navigate change, build capacity to withstand shocks, and locate sources of experimentation and innovation in face of uncertainty" (Ernston et al., 2010, p.531).

Underlying this is the 'inevitability' of climate change, the recognition that because of climate change we don't have choice but to learn how to adapt and to adopt an adaptive governance: "climate change is reinvigorating a need to 'cultivate new techniques of governance' for urban sustainability (...). The inevitability of climate change is turning attention increasingly to the question of adaptation" (Evans 2011, p.223).

In these conditions the meta-principles that are necessary to ensure the resilience of the system are flexibility, self-organization or creativity: "Diversity is thus seen as key for dealing with disturbance and change in productive ways, with self-organization and the capacity for learning and adaptation constituting important resilience characteristics" (Colding \& Barthel, 2013, p.156-157). For Gleeson (2008, p.2657) the imperative for this flexibility is "the continuous task of adaptation that must maintain the resilience of the urban system (...) [and] the interplay of evolution and adaptation (policy) (p.2658).

Baud \& Hordijk 2009's paper represents a good example of this literature. In their paper these authors discuss the main characteristics of resilience thinking and adaptive governance, focusing on those features relevant for urban planning in the context of uncertainty, unpredictability and change. According to them, these characteristics 
include: flexible institutions, knowledge systems that integrate different sets of knowledge, the capacities of learning by experiment, creativity, and self-organization. In a subsequent paragraph they contrast these characteristics of adaptive governance with current situations, and conclude that a number of recent trends in urban governance decentralization, the shift from government to governance and increased citizen participation - should in principle allow for more adaptive governance models, as they support (in theory) greater flexibility and autonomy at the local level.

Yet, Tanner and his colleagues (2009) point out that in some cases, the decentralisation of decision-making and political control can create conflicts and delays between agencies, hampering the development of climate resilient programming. In certain circumstances heavily top-down decision-making structures can help to implement programmes quickly, even if they often fail to allow participation of those people they are designed to help. In that regard, the quality of government at the local level has still a potentially greater impact on climate risk. Municipal governments are responsible for decisions on quality and provision of infrastructure, disaster preparedness and disaster response, and city planning development (i.e. preventing new development in areas of high risk or by not protecting areas which allow for buffer zones). Yet, recent evidence suggests that many municipal governments do not have adequate provisions in order to deal with increased climate hazards such as flood management. In well governed cities good provision for storm and surface drainage can easily be built into the urban fabric, along with complementary measures to protect flooding. But in poorly governed cities this does not happen - and it is common for buildings and infrastructure to be constructed in ways that actually disrupt drainage channels (Tanner et al., 2009).

These latest observations lead some to conclude that urban resilience rests (more) on social and governance dimension than on technical or ecological ones. Ernston and his colleagues for instance believe that "sustainability and resilience depend on a society's innovative capacity [and] solutions must be found by innovating in urban systems at different scales and across sectors. This firmly frames the urban system as an opportunity for sustainability and drives us to recognize that the answer to increased resilience might not lie in its ecological dimension, but rather in the social" (Ernston et al., 2011 p.538). Reflecting on water management issues on the urban context, Rijke et al. (2013, p.63) converge to the same conclusion: "Developing resilient water resource management systems is more a governance issue than a technological issue". To some extent this resonates well with Adger and his co-authors when they argue that:

"adaptation to climate change is limited by the values, perceptions, processes and power structures within society" (Adger et al., 2009, p. 349). 
Finally the literature on governance in urban context also highlights the importance of multi-level (or polycentric) governance system, which is considered crucial for enhancing resilience (Huitema et al., 2009; van de Meene et al., 2011). In a multilevel governance system, decision-making is dispersed across multiple centres of authority (Hooghe \& Marks, 2003). As such, it is the outcome of interaction between public sector agencies, private sector organisations and the community. Multi-level governance enables knowledge exchange and mutual adjustment of governance at different levels and sectors of governance (Agrawal, 2003) and potentially leads to synergetic effects (Ostrom \& Cox, 2010) that enable more adaptive governance regimes (Armitage et al., 2007). In sum, multi-level governance relies on a mix of formal institutions and informal networks (Olsson et al., 2006; Tompkins \& Adger, 2004) which are recognized to be critically important to account for, especially in the urban context in developing countries.

\section{Policy implications and concluding remarks}

The salient point that emerges from the above analysis is the recognition that a large number of different urban policies seem to link almost naturally with the resilience agenda. Put differently, resilience -understood in one or the other of the main narratives presented above- appear relevant to frame a large number of different problems/issues related to urban processes. In the light of this analysis we can identify at least three reasons why adopting a resilience narrative can have positive effect in the context of urban policy.

The first is the need to foster adaptation and flexibility in the planning process. Since resilience is by nature a concept which puts emphasis on the idea of adaptation and the dynamic nature of processes, we could reasonably assume that adopting a resilience narrative at the planning and implementation stages will contribute or facilitate the adoption of policies which endorse and reflect this adaptation feature. This is a clear characteristic of the ecological resilience narrative (e.g. Colding, 2007; Ahern, 2011), but also of the governance narrative (where innovation, transformation are characteristics that are presented as central elements) -see e.g., Baud \& Hordijk (2009) or Evans (2011). In the case of engineering resilience the situation is more ambiguous. While 'returning to the initial state' implies some degree of dynamic response (e.g. Kreimer et al., 2003, Wang \& Blackmore, 2009), some argue that this focus on persistence or stability may also prevent or hinder the system from embracing a fully adaptive or even transformative approach (Liao, 2012). 
Secondly, resilience is by nature a concept that emphasizes the importance of system thinking and system properties, including cross-scale dynamics and component interactions (Walkers et al., 2004; Folke, 2006). As such it has been instrumental in helping academics influencing the way urban planning is now conceptualized and applied in many cities (see e.g. Brown et al., 2012; Tyler \& Moench, 2012). There is also growing evidence of the importance of system characteristics such as flexibility, redundancy and modularity, or safe failure, as generic principles that are critical in the face of extreme events. Cities that are served by complex and interconnected systems (e.g. power, water, transportation, health, etc.) appear far less vulnerable to these extreme events than cities that are wholly dependent on one single central system, with few or no back-up options in the event of a failure (Da Silva et al., 2012).

Third, resilience is also a very useful concept as a way of integrating discourse, playing the role of a 'policy broker' that brings practitioners, policy-makers, organisations with different agendas, and communities of practice from different sectors together, around the same table, with the same objective: "strengthening (urban) resilience" (irrespective of what this term means exactly). Where piecemeal and siloed approaches are a major impediment for appropriate urban planning, resilience may appear a powerful tool to break these silos and ensure a more integrated planning and/or implementation process.

Yet, as the narrative analysis above has shown, the interpretations of what resilience is, what it is expected to achieve, what issues are at stake, and what characteristics of resilience are important, are rather varied and diverge widely across the spectrum. In fact, whether resilience should be used as a loose metaphor to 'inspire' the policy agenda as part of an integrated planning process, or as a rigorous analytical framework to solve a technical problem has not reached consensus yet, and both approaches are equally found in the literature. In other cases, some see resilience as the ultimate objective which should drive the entire urbanisation process, while others see or use it rather as a way to frame problems or even simply to stimulate discussions, either within a particular field, or across sectors and disciplines. Finally a few academics -and possibly a larger number of policy-makers- use it as a buzzword to attract attention or fundings, thus contributing to the uncomfortable feeling amongst others that resilience is sometimes nothing more than "old wine in a new bottle" used to perpetuate a businessas-usual process. 
The final point in this discussion builds on this last point and relates to another major potential limitation of the concept of resilience as revealed -or confirmed-by this review. It is the recognition that resilience may not provide the most appropriate framework to capture and reflect political economy processes -in the present case in relation to urbanization.

While urbanisation is often presented as a positive outcome of development (UNHabitat, 2011), it is also becoming increasingly evident that cities are also the place of extreme inequality, concentrated poverty and unemployment and high prevalence of malnutrition and associated heath issues (Ferré et al., 2011). Overall the percentage of the poor that live in urban areas is increasing (Ravallion et al., 2007; UNHabitat, 2013), raising questions about the distributional and equity dimension of urbanization. Recent global statistics reveal for instance that large sections of the urban population suffer from high levels of deprivation (Mitlin \& Satterthwaite, 2013) that can sometimes be even more debilitating than those experienced by the rural poor (Harpham, 2009). Conjointly, it is estimated that the number of slum dwellers in the developing world has risen from 767 million in 2000 to more than 860 million currently (UN-Habitat, 2013). In Sub-Sahara Africa, the number of slum dwellers has almost doubled over the past fifteen years and over $60 \%$ of the urban population currently lives in under-served informal settlements (UN-Habitat, 2013).

In that context it is revealing that none of the 58 articles that were reviewed in this analysis discussed or even mentioned these statistics. It seems instead that with few exceptions (e.g. de Zeeuw et al., 2011) the urban resilience literature has chosen to avoid embracing any strong social justice element and to promote (or at least acknowledge) more explicitly the needs and interests of the most marginalised and disenfranchised urban groups. Even the literature on governance in urban context, which insists that urban resilience should focus on polycentricity, transparency and accountability, and inclusiveness (e.g. Ahern, 2011), does not systematically seek to reveal how uncertainty and exposure to risks is experienced differently by different social groups in urban spaces.

As a consequence, none of the three narratives on urban resilience seems also able to acknowledge adequately the socially constructed aspects of resilience, i.e., the fact that the notion of resilience can be perceived, understood and experienced differently by different actors (rich, poor, men, women, old, young), or that the resilience of certain individuals or groups may be strengthened at the detriment of others (Hornborg, 2009; Davidson, 2010; Duit et al., 2010; Pelling \& Manuel-Navarrete, 2011). Without asking 
tough questions concerning whose and what resilience are being sustained or strengthened (Béné et al. 2014), the urban resilience literature risks promoting approaches that, not only, do not challenge the status quo, but may even reinforce it when the latter generates situations that are arguably socially and/or environmentally harmful (Cannon \& Muller-Mahn, 2010).

In essence, what seems to be missing in the present literature on urban resilience is the social justice and political dimension of the concept and a clearer understanding of the advantages but also the dangers of adopting such a concept as a new policy narrative without specifically acknowledging the political economy dimension of urbanization. While this absence of political economy does not matter much when talking about the resilience of materials, it began to matter with the resilience thinking of ecologists, especially when they insist (correctly) to include humans as part of the ecosystems. And it became absolutely critical when resilience is represented as desirable governance goal or quality that a city could have - and became in effect a quasi-political construct. 


\section{References}

Adger, N. W., Dessai, S., Goulden, M., Hulme, M., Lorenzoni, I., Nelson, D. R., Naess, L. O., Wolf, J. \& Wreford, A. (2009). Are there social limits to adaptation to climate change? Climatic Change, 93, 335-354.

Agudelo-Vera, C., Leduc, W., Mels, A. \& Rijnaarts, H. (2012). Harvesting urban resources towards more resilient cities. Resources, Conservation and Recycling, 64, 3-12.

Agrawal, A., (2003). Sustainable governance of common-pool resources: context, methods, and politics. Annual Review of Anthropology, 32, 243-262

Ahern, J. (2011). From fail-safe to safe-to-fail: sustainability and resilience in the new urban world. Landscape and Urban Planning, 100, 341-343.

Alberti, M. \& Marlzuff, J. (2004). Ecological resilience in urban ecosystem: linking urban patterns to human and ecological functions. Urban Ecosystems, 7, 241-265.

Allison H.E., Hobbs R.J. (2004). Resilience, Adaptive Capacity, and the Lock-in Trap of the Western Australian Agricultural Region. Ecology \& Society, 9(1) [online]

Antrobus, D. (2011). Smart green cities: from modernization to resilience? Urban Research \& Practice, 4(2), 207-214.

Armitage, D.R., Berkes, F., Doubleday, N., (2007). Adaptive Co-management: Collaboration, Learning, and Multi-level Governance. UBC Press, Vancouver, BC, Canada

Bahadur, A. V., Ibrahim, M. \& Tanner, T. (2010). The resilience renaissance? Unpacking of resilience for tackling climate change and disasters. CSR Discussion Paper No.1, Brighton: Institute of Development Studies, Strengthening Climate Resilience programme, $45 \mathrm{p}$.

Bahadur, A.V. \& Tanner, T.M. (2014). Transformational resilience thinking: Putting people, power and politics at the heart of urban climate resilience Environment and Urbanization, 26(1), 200-214.

Barthel, S. \& Isendahl, C. (2013). Urban gardens, agriculture, and water management: sources of resilience for long-term food security in cities. Ecological Economics, 86, 224-234.

Baud, I.S. \& Hordijk, M.A. (2009). Dealing with risks in urban governance: what can learn from 'resilience thinking'. The 4th International Conference of the International Forum on Urbanism 'The New Urban Question - Urbanism beyond Neo-Liberalism'. (pp.1069-1076).

Béné, C., Godfrey-Wood, R., Newsham, A. \& Davies, M. (2012). Resilience: New utopia or new tyranny? - Reflection about the potentials and limits of the concept of resilience in relation to vulnerability reduction programmes. IDS working Paper 405, Brighton: Institute of Development Studies, $61 \mathrm{p}$. 
Béné C. Newsham, A., Davies, M, Ulrichs M., \& Godfrey-Wood R. (2014). Resilience, poverty and development Journal of International Development 26: 598-623

Béné C., Headey D., Haddad L. \& von Grebmer, K. (2016). Is resilience a useful concept in the context of food security and nutrition programmes? Some conceptual and practical considerations Food Security [online DOI 10.1007/s12571-015-0526-x.

Berkes, F. \& Folke, C. (1998). Linking social and ecological systems for resilience and sustainability. In Berkes F. \& Folke C. eds., Linking social and ecological systems Management practices and social mechanisms for building resilience. (pp.1-25). Cambridge: Cambridge University Press.

Berkes, F., Colding, J. \& Folke, C. (2003). Navigating Social-Ecological Systems: Building Resilience for Complexity and Change. Cambridge: Cambridge University Press.

Bouzarovski, S., Salukvadze, J. \& Gentile, M. (2011). A socially resilient urban transition? the contested landscape of apartment building in two post-communist cities. Urban Studies, 48(13), 2689-2714.

Boyle, P. (2012). Risk, resilience, and urban governance: the case of the 2010 Winter Olympic Games. Canadian Review of Sociology 49(4), 350-369.

Boyle C, Mudd G, Mihelcic JR, Anastas P, Collins T, Culligan P, et al. (2010). Delivering sustainable infrastructure that supports the urban built environment.

Environmental Science and Technology, 44, 4836-4840.

Bridgman T., \& Barry D., 2002 Regulation is evil: An application of narrative policy analysis to regulatory debate in New Zealand Policy Sciences, 35, 141-161.

Brown, A., Dayal, A. \& del Rio, C. R. (2012). From practice to theory: emerging lessons from Asia for building climate change resilience. Environment and Urbanization, 24(2), 531-556.

Bull-Kamanga, L.; Diagne, K.; Lavell, A.; Lerise, F.; MacGregor, H.; Maskrey, A.; Meshack, M.; Pelling, M.; Reid, H.; Satterthwaite, D.; Songsore, J.; Westgate, K. \& Yitambe, A. (2003) Urban Development and the Accumulation of Disaster Risk and Other Lifethreatening Risks in Africa, Environment and Urbanization, 15(1), 193-204.

Burch, S. (2010). In pursuit of resilient, low carbon communities: an examination of barriers to action in three Canadian cities. Energy Policy, 38(12), 7575-7585.

Callister W.D. \& Rethwisch D.G. (2012). Fundamentals of Materials Science and Engineering - an integrated approach. 4th edition, John Wiley and Sons, $910 \mathrm{p}$.

Campanella, T. J. (2006). Urban resilience and the recovery of New Orleans. Journal of the American Planning Association, 72(2), 141-146.

Cannon, T. \& Muller-Mahn, D. (2010). Vulnerability, resilience and development discourses in context of climate change. Natural Hazards, 55(3), 621-635.

Carpenter, S.R., \& Folke, C. (2006). Ecology for transformation. Trends in Ecology and Evolution, 21, 309-315. 
Carpenter, S., Walker, B., Anderies, J. M., \& Abel, N. (2001). From Metaphor to Measurement: Resilience of What to What? Ecosystems, 4(8), 765-781.

Chapin, F. S. III, Kofinas, G. P., \& Folke, C. (Eds.) (2009). Principles of ecosystem stewardship: Resilience-based resource management in a changing world. New York: Springer-Verlag.

Chelleri, L., 2012. From the Resilient City to Urban Resilience. A review essay on understanding and integrating the resilience perspective for urban systems. Documents d'Anàlisi Geogràfica 58, 287-306.

Coaffe, J. (2008). Risk, Resilience, and environmentally sustainable cities. Energy Policy, 36, 4633-4638.

Cola F, Recine G, Alessandro G. (2005). Technologies Dossier Local New Energy Technology Implementation Project. Rome: Innova Spa; March, Sponsored by European Commission's Sixth Framework Programme.

Colding, J. (2007). 'Ecological land-use complementation' for building resilience in urban ecosystems. Landscape and Urban Planning, 81, 46-55.

Colding, J. \& Barthel, S. (2013). The potential of 'Urban Green Commons' in the resilience building of cities. Ecological Economics, 86, 156-166.

Cote, M., Nightingale, A.J. (2011). Resilience thinking meets social theory: situating social change in socio-ecological systems (SES) research. In: Progress in Human Geography, 1-15.

Crichton D. (2007). What can cities do to increase resilience? Philosophical Transactions of the Royal Society A (365), doi: 10.1098/rsta.2007.2081

da Silva, J., Kernaghan, S., \& Luque, A. (2012). A systems approach to meeting the challenges of urban climate change. International Journal of Urban Sustainable Development iFirst, 1-21 DOI:10.1080/19463138.2012.718279.

De Bruijn, K. M. (2004). Resilience indicators for flood risk management systems of lowland rivers. International Journal of River Basin Management, 2(3):199-210.

de Zeeuw, H., van Veenhuizen, R. \& Dubbeling, M. (2011). The role of urban agriculture in building resilient cities in developing countries. Journal of Agricultural Science, 149(S1), 153-163.

Davidson, D. J. (2010). The Applicability of the Concept of Resilience to Social systems: Some Sources of Optimism and Nagging Doubts. Society \& Natural Resources, 23(12), 1135-1149.

Department for International Development (DFID) (2011). Defining Disaster Resilience: A DFID Approach Paper, London: DFID, available at www.dfid.gov.uk/Documents/publications1/Defining-Disaster-Resilience-DFIDApproach-Paper.pdf (accessed 11 August 2012) 
Doughty, M.R.C., \& Hammond, G.P. (2004). Sustainability and the built environment at and beyond the city scale. Building and Environment, 39, 1223-1233.

Duit, A., Galaz, V. \& Eckerberg, K. (2010). Governance, complexity, and resilience. Global Environmental Change, 20, 363-368.

The Economist (2014) Building climate change resilience in cities -the private sector role, Intelligence Unit, http://www.economistinsights.com/sites/default/files/Urban\%20resilience\%20\%20exec\%20sum\%20-\%20WEB\%20-\%20FINAL\%20-\%2011.25.pdf

Ernstson, H., van der Leeuw, S., Redman, C., Meffert, D. \& Davis, G. et al. (2010). Urban transition: on urban resilience and human-dominated ecosystems. Ambio, 39(8), 531-545.

Evans, J. P. (2011). Resilience, ecology and adaptation in the experimental city. Transactions of the Institute of British Geographers, 36, 223-237.

Ferré, C., Ferreira, F. H.G., \& Lanjouw, P. (2011). Is there a metropolitan bias? The inverse relationship between poverty and city size in selected developing countries. Verona, Italy: Society for the Study of Economic Inequality (ECINEQ). Working Paper Series ECINEQ WP 2011 - 192. Available at http://www.ecineq.org/milano/WP/ECINEQ2011-192.pdf.

Fischer, F. \& Forester J. (1993). 'Editors' introduction,' in F. Fischer \& J. Forester, eds., The Argumentative Turn in Policy Analysis and Planning. Durham: Duke University Press, pp. 1-17

Folke, C. (2006). Resilience: The emergence of a perspective for social-ecological systems analyses. Global Environmental Change, 16(3), 253-267.

Gasper, R., Blohm, R., Ruth, M., 2011. Social and economic impacts of climate change on the urban environment. Current Opinion of Environmental Sustainability, 3, 150157

Glantz, M. D., \& Johnson, J. L. (1996). Resilience and Development. New York: Kluwer Academic.

Gleeson, B. (2008). Critical commentary: walking from the dream: an Australian perspective on urban resilience. Urban Studies, 45(13), 2653-2668.

Global Monitoring Report (2013). Rural-Urban Linkages and the MDGs. World Bank and IMF

Gordon R.B., Bertram M., \& Graedel T.E. (2006). Metal stocks and sustainability. Proceedings of the National Academy of Sciences of the United States of America, 103, 1209-1214.

Harpham, T. (2009). Urban health in developing countries: What do we know and where do we go? Health \& Place, 15(1), 107-116. 
Holling, C. S. (1973). Resilience and stability of ecological systems. Annual Review of Ecology and Systematics, 4, 2-23

Hooghe, L., \& Marks, G., 2003. Unraveling the central state, but how? Types of multilevel governance. American Political Science Review, 97, 233-243.

Hornborg, A. (2009). Zero-sum World: Challenges in Conceptualizing Environmental Load Displacement and Ecologically Unequal Exchange in the World-system. International Journal of Comparative Sociology, 50(3-4), 237-262. Available at www.lucid.lu.se/Hornborg_2009_zero_sum_world.pdf. Accessed 11 August 2012. Huitema, D., Mostert, E., Egas, W., Moellenkamp, S., Pahl-Wostl, C., \& Yalcin, R., (2009). Adaptive water governance: assessing the institutional prescriptions of adaptive (co-)management from a governance perspective and defining a research agenda. Ecology \& Society, 14, 26.

ICLEI, (2011) Resilient cities Proceedings of the 2 nd World Congress on Adaptation and Climate Change, Otto-Zimmermann, Konrad (Ed.) available from http://resilientcities.iclei.org/resilient-cities-hub-site/about-the-global-forum/resilient-cities-2011/ IFRC, (2004). World Disaster Report - focus on community resilience. Geneva: International Federation of Red Cross and Red Crescent Societies, 232 p. Intergovernmental Panel on Climate Change IPCC (2012). Managing the Risks of Extreme Events and Disasters to Advance Climate Change Adaptation. A Special Report of Working Groups I and II of the Intergovernmental Panel on Climate Change, Field CB, Barros V, Stocker TF, Qin D, Dokken DJ, Ebi KL, Mastrandrea MD, Mach KJ, Plattner G-K, Allen SK, Tignor M, Midgley PM. (Eds) Cambridge, UK: Cambridge University Press

Interagency Resilience Working Group (IRWG) (2012). The Characteristics of Resilience Building A, Interagency Resilience Working Group discussion paper, http://community.eldis.org/resiliencewg/[accessed 11 August 2012]

Jansson, A. (2013). Reaching for a sustainable, resilience urban future using the lens of ecosystem services. Ecological Economics, 86, 285-291.

Jansson, A. \& Polasky, S. (2010). Quantifying biodiversity for building resilience for food security in urban landscapes. Ecology \& Society, 15(3)

Khailani, D. K. \& Perera, R. (2013). Mainstreaming disaster resilience attributes in local development plans for the adaptation to climate change induced flooding: A study based on the local plan of Shah Alam City, Malaysia . Land Use Policy, 30(1), 615627.

Klein, R.J.T., Smit, M.J., Goosen, H., \& Hulsbergen, C.H., (1998). Resilience and vulnerability: coastal dynamics or Dutch dikes? The Geographical Journal, 164(3), 259-268. 
Kreimer, A., Arnold, M. \& Carlin, A. (2003). Building safer cities: the future of disaster risk. Disaster Risk Management Series No. 3, The World Bank, available at: www. preventionweb.net/files/638_8681.pdf (accessed 22 February 2012)

Lavell, A.; Wisner, B.; Cannon, T. \& Pelling, M. (2003) The Vulnerability of Cities: Natural Disasters and Social Resilience, London: Earthscan.

Leach, M. (2008). Re-framing Resilience: A Symposium Report, STEPS Working Paper 13, Brighton: Institute of Development studies.

Leduc W., Agudelo C., Rovers R., \&Mels A. (2009) Expanding the exergy concept to the urban water cycle. In: Proceedings of the SASBE conference.

Leichenko, R. (2011). Climate change and urban resilience. Current Opinion in Environmental Sustainability, 3, 164-168.

Levine, S., Pain, A., Baley, S. \& Fan, L. (2012). The relevance of 'resilience'? HPG Policy Brief 49, London: Overseas Development Institute, Humanitarian Policy Group, 4 p.

Liao, K.-H. (2012). A theory on urban resilience to floods - a basis for alternative planning practices. Ecology \& Society, 17(4), 48.

Malalgoda, C., Amaratunga, D. \& Haigh, R. (2013). Creating a disaster resilient built environment in urban cities - the role of local governments in Sri Lanka. International Journal of Disaster Resilience in the Built Environment, 4(1), 72-94.

Martin-Breen, P., Anderies, J.M. (2012). Resilience: a literature review. Brighton: Institute of Development Studies, Resource Alliance and Rockefeller Foundation for the Bellagio Initiative, $67 \mathrm{p}$.

Milman, A. \& Short, A. (2008). Incorporating resilience into sustainability indicators: and example for the urban water sector. Global Environmental Change, 18(4), 758-767.

Mitlin, D., \& Satterthwaite, D. (2013). Urban poverty in the global South: scale and nature. New York: Routledge.

Monteiro, A., Carvalho, V., Velho, S. \& Sousa, C. (2012). Assessing and monitoring urban resilience using COPD in Porto. Science of the Total Environment, 414, 113-119.

Moser, C., Norton, A., Stein, A. \& Georgieva, S. (2010). Pro-poor adaptation to climate change in urban centers: case studies of vulnerability and resilience in Kenya and Nicaragua. Report No.54947-GLB, World Bank, Social Development Department, 96 p.

Olsson, P., Gunderson, L., Carpenter, S., Ryan, P., Lebel, L., Folke, C. \& Holling, C. (2006). Shooting the rapids: navigating transitions to adaptive governance of socialecological systems. Ecology and Society 11(18)

Ostrom, E., Cox, M., (2010). Moving beyond panaceas: a multi-tiered diagnostic approach for social-ecological analysis. Environmental Conservation, 37, 451-463

Pearson, L. J. (2013). In search of resilient and sustainable cities: prefatory remarks. Ecological Economics, 86, 222-223. 
Pelling, M. \& Manuel-Navarrete, D. (2011). From resilience to transformation: the adaptive cycle in two Mexican urban centers. Ecology \& Society, 16(2), 11. [online] URL: http://www.ecologyandsociety.org/vol16/iss2/art11/.

Pickett, S. T., Cadenasso, M. L. \& Grove, J. M. (2004). Resilient cities: meaning, models, and metaphor for integrating the ecological, socio-economic and planning realms. Landscape and Urban Planning, 69, 369-384.

Ravallion, M., Chen, S., \& Sangraula, P. (2007). New Evidence on the Urbanization of Global Poverty. Washington, D. C.: World Bank. Policy Research Working Paper 4199.

Rijke, J., Farelly, M., Brown, R. \& Zevenbergen, C. (2013). Configuring transformative governance to enhance resilient urban water systems. Environmental Science and Policy, 25, 62-72.

Resilience Alliance, (2007). Research Prospectus - A Resilience Alliance Initiative for Transitioning Urban Systems towards Sustainable Futures. CSIRO, Australia, Arizona State University, USA Stockholm University, Sweden, 24 p.

Resilientcity.org (2010) Resilience, available at http://www.resilientcity.org/index.cfm?pagepath=Resilience\&id=11449

Rockström, J., Steffen, W., Noone, K., Persson, Å., Chapin, F.S., Lambin, E.F., et al. (2009). A safe operating space for humanity. Nature, 461, 472-475.

Roe, E.M. (1989). Narrative analysis for the policy analyst: A case study of the 1980-1982 medfly controversy in California. Journal of Policy Analysis and Management, 8(2), 251-273.

Roe, E.M. (1994). Narrative Policy Analysis: Theory and Practice. Durham: Duke University Press.

Romero-Lankao, P., \& Dodman, D. (2011). Cities in transition: Transforming urban centers from hotbeds of GHG emissions and vulnerability to seedbeds of sustainability and resilience: Introduction and editorial overview. Current Opinion in Environmental Sustainability, 3, 113-120

Rotmans, J., Kemp, R., van Asselt, M., (2001). More evolution than revolution: transition management in public policy. Foresight, 3, 15-31.

Shaw, R., Razafindrabe, B., Gulshan, P. \& Takeuchi, Y. (2009). Climate disaster resilience: focus on coastal urban cities in Asia. Asian Journal of Environment and Disaster Management, 1, 101-116.

Smith, T. F., Daffara, P., O'Toole, K., Matthews, J., Thomsen, D., Inayatullah, S. , Fien, J. \& Graymore, M. (2011). A method for building community resilience to climate change in emerging coastal cities. Futures, 43, 673-679. 
Tanner, T., Mitchell, T., Polack, E. \& Guenther, B. (2009). Urban governance for adaptation: assessing climate change resilience in ten Asian cities. IDS Working Paper 315, Brighton: Institute of Development Studies, $47 \mathrm{p}$.

Tobin, G. (1999). Sustainability and community resilience: the holy grail of hazards planning? Global Environmental Change Part B: Environmental Hazards, 1(1), 13-25.

Tompkins, E.L., Adger, W.N., 2004. Does adaptive management of natural resources enhance resilience to climate change? Ecology \& Society, 9, 10.

Twigg, J. (2007). Characteristics of a Disaster-resilient Community'. London: Department for International Development, DFID DRR Interagency Coordination Group.

Tyler, S. \& Moench, M. (2012). A framework for urban climate resilience. Climate and Development, 4(4), 311-326.

UCCRN (2011). Climate change and cities - first assessment report of the Urban Climate Change Research Network - Executive Summary. New York: Columbia University, Urban Climate Change Research Network (UCCRN).

UN-Habitat (2011). State of the World's Cities 2010/2011 Bridging the urban divide, United Nations Human Settlements Programme, Earth scan, Nairobi, 244 p.

UN-HABITAT. (2013). Streets as Public Spaces and Drivers of Urban Prosperity. New York: Global Urban Observatories Unit.

van de Meene, S., Brown, R., Farrelly, M., (2011). Towards understanding governance for sustainable urban water management. Global Environmental Change, 21, 11171127

von Grebmer, K., D. Headey, C. Béné, L. Haddad et al. (2013). 2013 Global Hunger Index: The Challenge of Hunger: Building Resilience to Achieve Food and Nutrition Security. Bonn, Washington, DC, and Dublin: Welthungerhilfe, International Food Policy Research Institute, and Concern Worldwide.

Walker, B., Carpenter, S., Anderies, J., Abel, N., Cumming, G. S., Janssen, M., Lebel, L. N. J., Peterson, G. D. \& Pritchard, R. (2002). Resilience management in social-ecological systems: a working hypothesis for a participatory approach. Conservation Ecology, 6, on-line.

Walker, B., Holling, C. S., Carpenter, S. R. \& Kinzig, A. (2004). Resilience, adaptability and transformability in social-ecological systems. Ecology and Society, 9(5), [on-line]

Walker, B. H., Anderies, J. M., Kinzig, A. P. \& Ryan, P. (2006). Exploring Resilience in Social-Ecological Systems through Comparative Studies and Theory Development: Introduction to the Special Issue. Ecology \& Society, 11(1) [online]

Wallace, R., Wallace, D., Ahern, J. \& Galea, S. (2007). A failure of resilience: estimating response of New York City's public health ecosystem to sudden disaster. Health \& Place, 13, 545-550. 
Wang. C., \& Blackmore, J. M. (2009). Resilience concepts for water resource systems. Journal of Water Resources Planning and Management, 135(6):528-536.

Wardekker, J. A., de Jong, A., Knoop, J. M. \& van der Sluijs, J. P. (2010). Operationalizing a resilience approach to adapting an urban delta to uncertain climate changes.

Technological Forecasting \& Social Change, 77, 987-998.

WCDR, (2005). Building the Resilience of Nations and Communities to Disasters, World Conference on Disaster Reduction 18-22 January 2005, Kobe, Japan. United Nations International Strategy for Disaster Reduction

World Bank, (2012). A Workbook on Planning for Urban Resilience in the Face of Disasters Adapting Experiences from Vietnam's Cities to Other Cities, Fatima Shah \& Federica Ranghieri (eds.), The World bank, Washington, 200p. 
Table 1. The different levels of definition of the term resilience as found in the urban resilience literature

\begin{tabular}{|c|c|c|}
\hline Nature of the definition & Examples & meaning \\
\hline $\begin{array}{l}\text { - a clear (academic) concept (relying on } \\
\text { theory) }\end{array}$ & $\begin{array}{l}\text { Agudelo Vera et al. (2012); Colding } \\
\text { (2007); Barthel and Isendahl (2012) }\end{array}$ & \multirow[t]{2}{*}{ specific } \\
\hline $\begin{array}{l}\text { - a clear (academic) concept (relying on } \\
\text { theory) and applied / transferred to } \\
\text { cities/urban entities }\end{array}$ & $\begin{array}{l}\text { Leichenko, (2011); Malalgoda et al. } \\
\text { (2013); Monteiro et al. } 2012\end{array}$ & \\
\hline $\begin{array}{l}\text { - a series of definitions (pluralistic } \\
\text { approach) }\end{array}$ & $\begin{array}{l}\text { Baud and Hordijk (2009); Pearson } \\
\text { (2013) }\end{array}$ & \\
\hline - a common word meaning & Boyle (2012) & \\
\hline - implicit definition & $\begin{array}{l}\text { Bouzarovski et al. (2011); Gleeson } \\
\text { (2008) }\end{array}$ & \\
\hline - no definition & Crichton (2007) & \\
\hline
\end{tabular}


Table 2. The different ways the term 'resilience' is used in the urban resilience literature

Use Examples

- a goal (what to aim at)

Energy resilience: reliable supplies and stable costs

of energy (Coaffe 2008)

- an analytical tool (to understand the problem

Resilience theory to develop a better approach to and find better solution) urban flood (Liao 2012)

- a metaphor (to help break silo)

Resilience as a metaphor to help link ecology and planning (Pickett et al. 2004)

- an indicator (of sustainability)

Milman and Short (2008); Monteiro et al. (2013)

- a buzz-word (as a strategy to publish or attract fund?)

- no use beyond the title (part of the

Wallace et al. (2007); Burch (2010) buzzword?) 
Table 3. Resilience as a goal for urbanisation - through different pathways

\begin{tabular}{|c|c|c|c|c|c|c|c|}
\hline The problem & & The process & & The practice & & The goal & Reference \\
\hline - Climate change & $\gg$ & - Adaptation & $\gg$ & - Planning experimentation & $\gg$ & Resilience & Evans (2011) \\
\hline $\begin{array}{c}\text { - Unsustainable } \\
\text { urbanization }\end{array}$ & $>>$ & $\begin{array}{l}\text { - Technical } \\
\text { change }\end{array}$ & $>>$ & - Urban harvest & $>$ & Resilience & $\begin{array}{l}\text { Agudelo Vera et } \\
\text { al. (2012) }\end{array}$ \\
\hline - Food insecurity & $>>$ & $\begin{array}{l}\text { - Increase food } \\
\text { availability }\end{array}$ & $>>$ & - Peri-urban Agriculture & $>$ & Resilience & $\begin{array}{l}\text { de Zeeuw et al. } \\
\text { (2011) }\end{array}$ \\
\hline $\begin{array}{c}\text { - Unsustainable } \\
\text { urbanization }\end{array}$ & $>>$ & $\begin{array}{l}\text { - Biodiversity } \\
\text { conservation }\end{array}$ & $\gg$ & - Urban Green Commons & $\gg$ & Resilience & $\begin{array}{l}\text { Colding and } \\
\text { Barthel (2013) }\end{array}$ \\
\hline - Climate change & >> & - Social change & $\gg$ & - Transformative governance & $\gg$ & Resilience & Rijke et al. (2013) \\
\hline
\end{tabular}


Table 4. The use of resilience as an analytical framework to 'solve' urban issues.

\begin{tabular}{|c|c|c|c|c|c|c|}
\hline The Problem & & The framework & Meta-Principles & & The outcome & References \\
\hline $\begin{array}{l}\text { - Cities vulnerable } \\
\text { to food shortage }\end{array}$ & $>>$ & $\begin{array}{l}\text { - Social-ecological } \\
\text { resilience }\end{array}$ & $\begin{array}{l}\text { - diversity and } \\
\text { memory }\end{array}$ & $>>$ & - Food security & $\begin{array}{l}\text { Barthel and } \\
\text { Isendahl } 2012\end{array}$ \\
\hline $\begin{array}{l}\text { - Cities need to } \\
\text { adapt }\end{array}$ & $>>$ & $\begin{array}{l}\text { - Social-ecological } \\
\text { resilience }\end{array}$ & $\begin{array}{l}\text { - multi-functionality } \\
\text { redundancy and, } \\
\text { adaptive planning }\end{array}$ & $>>$ & $\begin{array}{l}\text { - Resilient } \\
\text { Sustainability }\end{array}$ & Ahern 2011 \\
\hline $\begin{array}{l}\text { - Cities need to } \\
\text { adapt }\end{array}$ & $>$ & $\begin{array}{l}\text { - Social-ecological } \\
\text { resilience }\end{array}$ & $\begin{array}{l}\text { - capacities of learning } \\
\text { flexible institutions } \\
\text { self-organization }\end{array}$ & $>>$ & $\begin{array}{l}\text { - Adaptive } \\
\text { Governance }\end{array}$ & $\begin{array}{l}\text { Baud and } \\
\text { Hordijk } 2009\end{array}$ \\
\hline
\end{tabular}


Table 5. The three main narratives on urban resilience

\begin{tabular}{|c|c|c|c|}
\hline Narratives & $\begin{array}{l}\text { Urban hazards and disaster } \\
\text { risk reduction }\end{array}$ & Urban ecological resilience & $\begin{array}{l}\text { Urban resilience through } \\
\text { governance and institutions }\end{array}$ \\
\hline References & $\begin{array}{l}\text { Bull-Kamanga et al. 2003; } \\
\text { Lavell et al. 2003; } \\
\text { Campanella 2006; Shaw et } \\
\text { al. 2009; Wardekker et al. } \\
\text { 2010; Smith et al. 2011; Liao } \\
\text { 2012; Khailani and Perera } \\
\text { 2013; Malalgoda et al. } 2013\end{array}$ & $\begin{array}{l}\text { Alberti and Marzluff 2004; } \\
\text { Colding 2007; Leduc et al. } \\
\text { 2009; Jansson and Polasky } \\
\text { 2010; Agudelo Vera et al. } \\
\text { 2012; Colding and Barthel } \\
\text { 2013; Jansson } 2013\end{array}$ & $\begin{array}{l}\text { Wallace et al. 2007; Gleeson } \\
\text { 2008; Tanner et al. 2009; } \\
\text { Wardekker et al. 2010; } \\
\text { Evans 2011; Pelling and } \\
\text { Manuel-Navarrete 2011; } \\
\text { Ahern 2011; Ernston et al. } \\
\text { 2011; Rijke et al. } 2013\end{array}$ \\
\hline The problem & $\begin{array}{l}\text { Climate-change related } \\
\text { extreme events are } \\
\text { threatening urban centers }\end{array}$ & $\begin{array}{l}\text { Urbanization as currently } \\
\text { implemented is } \\
\text { (ecologically) } \\
\text { unsustainable }\end{array}$ & $\begin{array}{l}\text { Urban centers and planners } \\
\text { need to be able to adapt to } \\
\text { their uncertain environment }\end{array}$ \\
\hline Type of resilience & Engineering resilience & Ecological resilience & Social resilience \\
\hline $\begin{array}{l}\text { What is needed? } \\
\text { (Resilience } \\
\text { characteristics) }\end{array}$ & $\begin{array}{l}\text { Robustness } \\
\text { - Infrastructure } \\
\text { - Buffering } \\
\text { - Resistance } \\
\text { - Protection } \\
\text { - Recovery }\end{array}$ & $\begin{array}{l}\text { Adaptation } \\
\text { - (bio)diversity } \\
\text { - Diversification } \\
\text { - (urban) ecosystem } \\
\quad \text { services }\end{array}$ & $\begin{array}{l}\text { Governance } \\
\text { - Social innovation } \\
\text { - Decentralization } \\
\text { - Participation } \\
\text { - Poly-centric governance }\end{array}$ \\
\hline
\end{tabular}




\section{End Notes}

${ }^{i}$ This sub-section does not refer exclusively to the 58 articles included in the narrative analysis. All the other sub-sections of the narrative analysis however do. 


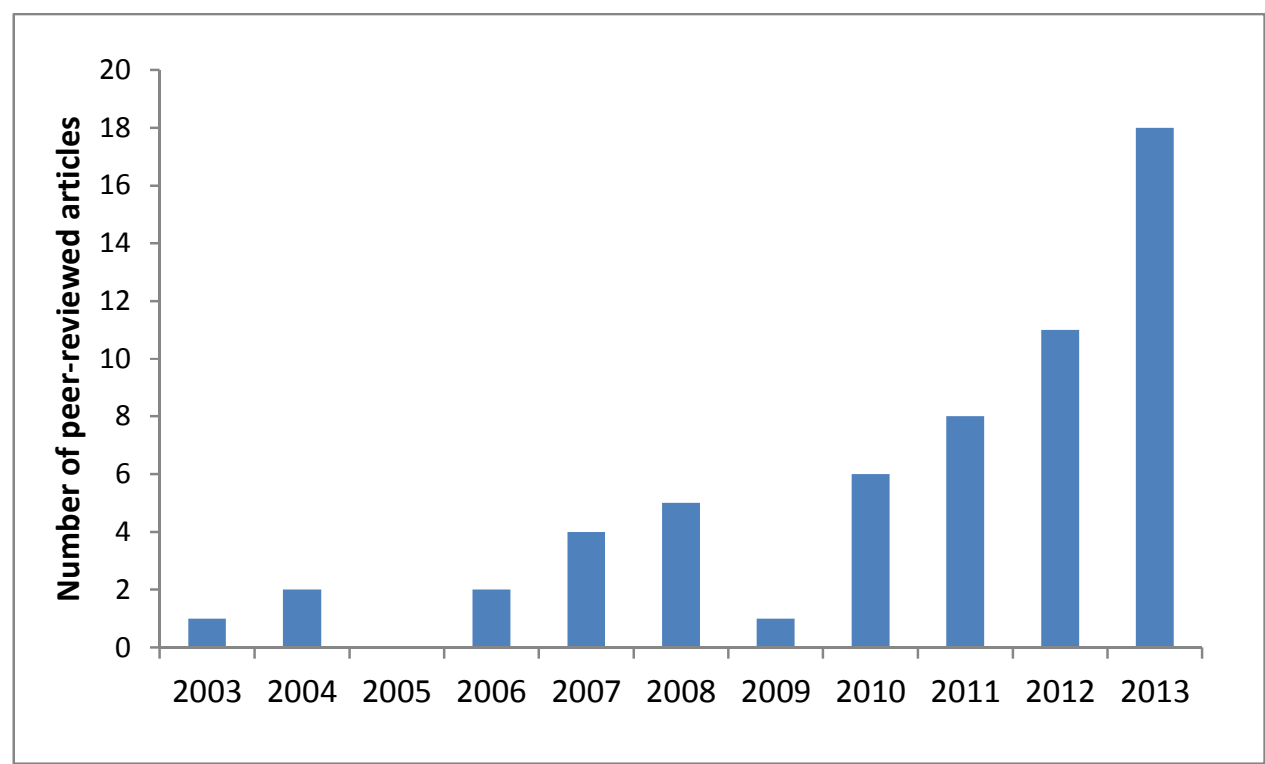

Fig.1. Number of peer-reviewed articles published on urban resilience (see details in text). 


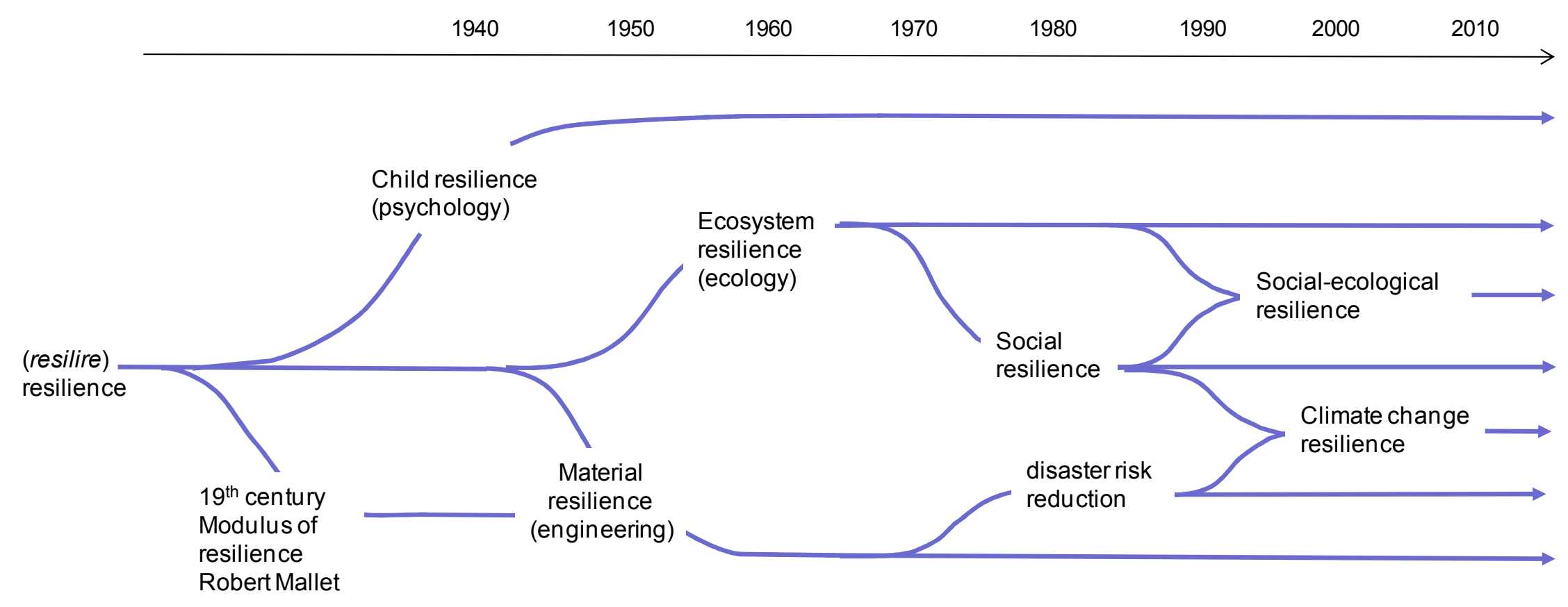

Fig.2. Evolutionary path of the concept of resilience and emergence of its different epistemological lineages. 


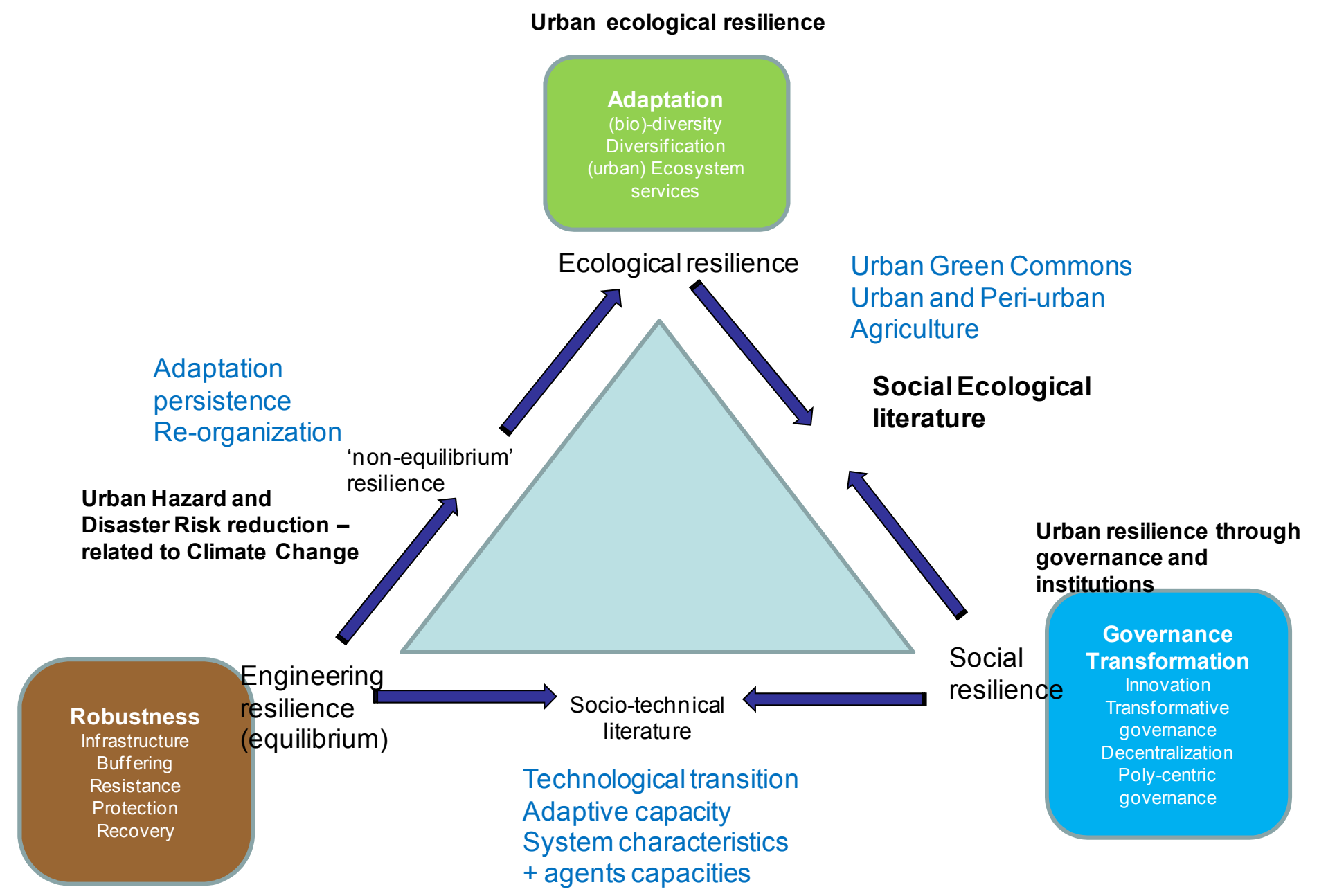

Fig.3. Static map of the resilience narratives related to urbanization 